\title{
Penile Gangrene due to Strangulation by a Metallic Nut: A Case Report
}

\author{
La gangrène du pénis par strangulation par un écrou métallique: \\ Un rapport de cas
}

\author{
A. Nuhu*, S. T. Edino ${ }^{\dagger}$, G. O. Agbese ${ }^{\ddagger}$, M. Kallamu
}

\begin{abstract}
BACKGROUND: Penile entrapment and subsequent strangulation is a serious injury that requires a prompt treatment to avoid gangrene.

OBJECTIVE: We report our experience dealing with a case of penile gangrene following strangulation by a metallic nut in a middle aged Nigerian.

METHODS: We summarise the case history, physical findings, investigations and operative treatment of a middle aged man who slipped a round metallic nut over his penis, entrapping it for five days causing strangulation and subsequent gangrene. The literature on penile entrapment, strangulation and gangrene is also reviewed.

RESULTS: The patient presented with acute urinary retention and had complete gangrene of the penis. Suprapubic cystostomy was done and he had total penile amputation and perineal urethrostomy

CONCLUSION: Entrapment of the penis leading to strangulation is a rare condition that needs urgent relief, otherwise penile gangrene sets in, the treatment of which has very serious consequences. WAJM 2009; 28(5): 340-342.
\end{abstract}

Keywords: Penile gangrene, metallic nut, suprapubic cystostomy, penile amputation.

\section{RÉSUMÉ}

CONTEXTE: Penile provocation policière et de l'étranglement postérieure est une blessure grave qui nécessite un traitement rapide pour éviter la gangrène.

OBJECTIF: Nous rapportons notre expérience face à un cas de gangrène du pénis après la strangulation par un écrou métallique dans un âge moyen nigériane.

MÉTHODES: Nous résumons l'histoire de cas, les signes physiques, les enquêtes et le traitement chirurgical d'un homme d'âge moyen qui a glissé un écrou métallique rond sur son pénis, il piéger pendant cinq jours causant la strangulation et la gangrène ultérieures. La littérature sur le piégeage du pénis, l'étranglement et la gangrène est aussi examiné.

RÉSULTATS: Le patient a présenté une rétention urinaire aiguë et avaient la gangrène complète du pénis. Cystostomie sus-pubienne a été fait et il a subi une amputation du pénis et du périnée total urétérostomie

CONCLUSION: La provocation policière du pénis conduit à l'étranglement est une maladie rare qui a besoin de secours d'urgence, sinon la gangrène du pénis, dont le traitement a des conséquences très graves. WAJM 2009; 28 (5): 340-342.

Mots-clés: la gangrène du pénis, d'écrous métalliques, cystostomie sus-pubienne, l'amputation du pénis.

\footnotetext{
*Department of Surgery, University of Maiduguri Teaching Hospital, P.M.B. 1414, Maiduguri, Borno State, Nigeria. Department of Surgery, Aminu Kano University Teaching Hospital Kano, Kano State Nigeria. Department of Surgery, Federal Medical Center Azare, Bauchi State, Nigeria.

Correspondence: Dr A. Nuhu, E-mail: nuhualinvwa@yahoo.com Tel: +234 806501255

Abbreviations: ATS, Anti tetanus serum; EPC, Emergency suprapublic cystostomy; EUCr, Electrolytes, urea and creatinme; GCS, Glasgow coma score; PCV, packed cell volume; RBS, Random blood sugar;
} 


\section{INRODUCTION}

Entrapment of the penis leading to strangulation and possible gangrene is a rare but very serious injury, whose definitive treatment could have disastrous consequences on the patient. ${ }^{1,2}$ Cases caused by metal rings, ${ }^{2,3}$ plastic or glass bottles, ${ }^{1,4,6}$ hammer heads ${ }^{5}$ and many other objects have been described. The motive behind the action varied as the objects responsible for the injury but could be delibrate for mastubation or to improve sexual performance. ${ }^{3,5}$ In other instances the patient could have some psychiatric or psychosexual problems..$^{5}$ The mode of removal and definitive treatment depends on the nature of the constricting object, for how long it has been there and equipment available. ${ }^{6} \mathrm{~A}$ whole range of varying degrees of penile injury are possible from skin uceration, urethral injuries and development of fistulae, to loss of penile sensation and gangrene. ${ }^{7}$ There are no definite protocols for treatment but strangulating objects most be removed rapidly to prevent penile gangrene. We report a patient who had a thick metallic nut at the root of his penis for days and presented with total penile gangrene and acute urinary retention.

\section{Case Report}

A60-year-old Nigerian presented to the accident and emergency department in acute urinary retention and a total infected gangrene of the penis. He is known to have some form of mental illness for 20 years. Before then he was a successful businessman married to one wife and has four children. He left home to an undisclosed destination and was found five days latter in a near by farm in urine retention and a thick metallic nut entrapping his penis at the base (Fig. 1). He was said to have passed the nut himself after trying it on his fingers and finding it to be too wide for all of them. He could give no reasons for his action and claimed the nut has been there for only a day.

Physical examination revealed an unkempt elderly man not in any distress (urine retention was earlier relieved by suprapubic tapping by the casualty nurse), he was neither pale nor dehydrated. He was conscious and alert, with a Glasgow Coma Score (GCS) of 15. The pulse rate was 98 beats/minute, blood pressure of $150 / 90 \mathrm{mmHg}$, respiratory rate of 24 cycles/minute and axillary temperature of $37.5^{\circ} \mathrm{C}$. There was a tense, tender and cystic suprapubic mass (suggesting a full bladder). External genitalia revealed a huge nut entrapping the penis at its root with overt features of gangrene. The right scrotal sac was hypotrophic and contained no testicle. The left hemi-scrotum and testicle were normal (Fig. 1). The packed cell volume (PCV) was $35 \%$, serum electrolytes, urea and creatinine (EUCr) were within normal limits, and the random blood sugar (RBS) was $8.3 \mathrm{mmol} / \mathrm{L}$. The suprapubic urine sample was positive for blood $(++)$, protein $(+)$, glucose $(++)$, and ascorbic $\operatorname{acid}(+)$ and had $\mathrm{a}_{\mathrm{H}}$ of 5 .

He was placed on intravenous (IV) normal saline, and IV Ceftriazone one gram in combination with $500 \mathrm{mg}$ of IV metronidazole. He also had tetanus toxoid $0.5 \mathrm{mg}$ as single dose and $1,500 \mathrm{IU}$ of

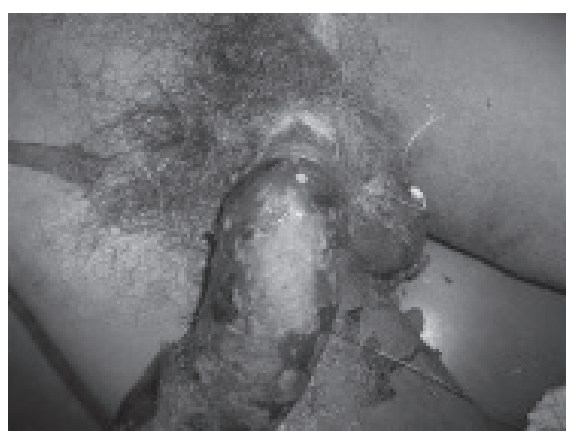

Fig. 1: At presentation, note the black edematous penile shaft and the approximately $40 \mathrm{~mm}$ long and $10 \mathrm{~mm}$ thick metallic nut at the root, which has been there for 5 days.

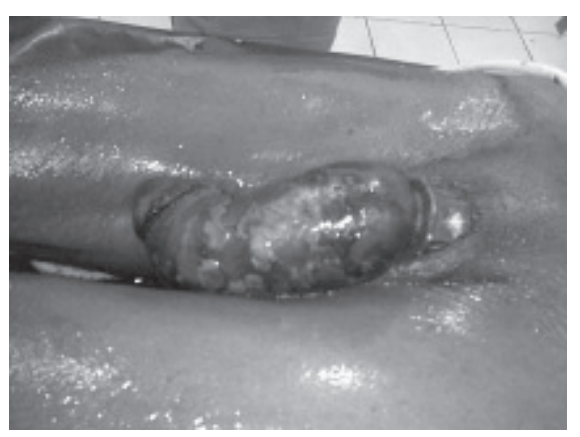

Fig. 2: Just before penile amputation, gangrene and strangulating metallic nut is more obvious. Note the suprapubic catheter. equine anti-tetanus serum (ATS). He had an emergency suprapubic cystostomy (SPC) in the casualty followed a few hours latter by a total penile amputation and a perineal urethrostomy, leaving a urethral stent which was removed after seven days (Fig. 2). There was slight discharge from the urethrostomy site which cleared with twice daily dressing. The SPC catheter was spigoted and patient was able to pass urine with a good stream. The psychiatrist is managing the patient as a schizophrenic. The patient was discharged 14 days postoperative to be followed up in the surgical out-patient department.

\section{DISCUSSION}

Total gangrene of the penis is not a common lesion. When it occurs, it may be due to Fournier's gangrene,${ }^{8}$ peripheral occlusive vascular disease, ${ }^{9}$ or in some occasional patients a complication of diabetes. ${ }^{10,11}$ Strangulating agents used on the penis (an important cause of gangrene) was reported in the literature as far back as $1755^{12}$ and since then about 60 cases have been reported in the world literature ${ }^{1}$. The majority of strangulating penile injuries are self inflicted and the motives are as varied as the constricting agents. In the majority of patients, it is for erotic and autoerotic reasons, ${ }^{4,5,6,13}$ in children it may be placed by ignorant parents to prevent enuresis ${ }^{4}$ and others due to psychosexual or psychiatric disorders. ${ }^{4}$ Agents of penile constriction, leading to strangulation and gangrene in some instances are varied but generally the metallic objects, e.g. nuts, bolts, washers, hammer heads etc are most commonly encountered. ${ }^{13}$ Plastic and other less solid materials are said to cause more severe injuries than the metallic objects. $^{4,7,13}$

At presentation, the patients are unable to remove the constricting agents after attaining an erection, and tumescence is not possible because of occlusion of the vessels, starting with the veins. If the patient presents at this stage, (when only the penile veins are occluded), that is within 48 hours or less there will be gross penile oedema but intact distal penile sensation. If the presentation is late, that is 72 hours and more, there is arterial occlusion and 
gradual loss of penile sensation with danger of gangrene. ${ }^{13}$ Acute urinary retention occurs early in the progression because the urethra is superficial, (covered by a thin layer of corpus spongiosum) on the ventral aspect of the penis. The reason for late presentation in a patient with no psychiatric problems is the intense feeling of shame and embarrassment, whereas the psychiatric patient may simply neglect the injury until it is too late.

The diagnosis is obvious. A complete psychiatric evaluation was necessary in the index patient and removal of the gangrenous phallus must be prompt to prevent septicaemia and/or tetanus developing. The neglected case will also require adequate resuscitation; intravenous fluids and broad spectrum potential antibiotics. The consent for operation had to be obtained from the close relatives. Psychiatric care is needed

Table 1: Bhat's Grading of Penile Gangrene

\begin{tabular}{ll}
\hline Grade & Description \\
\hline Grade I: & $\begin{array}{l}\text { Oedema of the distal penis. } \\
\text { No evidence of skin } \\
\text { ulceration or urethral injury. }\end{array}$
\end{tabular}

Grade II: Injury to skin and constriction of corpus spongiosum, but no evidence of urethral injury. Distal penile oedema and decreased penile sensation.

Grade III: Injury to skin and urethra but no urethral fistula. Loss of distal penile sensations.

Grade IV: Complete division of corpus spongiosum leading to urethral fistula and constriction of corpora carvernosa with loss of distal penile sensations.

GradeV: Gangrene, necrosis, or complete amputation of distal penis. to rehabilitate the patient to accept the perineal urethrostomy.

There are no laid down protocols for the removal of these objects. The technique of removal and equipment needed is dependent on the constricting agent and the length of time of strangulation. However, prompt removal and decompression of the phallus is the aim in all cases as this will stop vascular, nervous and urethral injury and ensure optimal erection and urine flow. Delay in treatment is due to late presentation, the most severe consequence being complete penile gangrene. Bhat et $a l^{7}$ graded this injury into five, a useful guide to definitive treatment:

Our patient is clearly a case of severe injury with vascular insult leading to complete gangrene (Grade V) and therefore was treated by total penile amputation and suprapubic cystostomy to divert the urine. The perineal urethrostomy was supported by a urethral sent for seven days to allow for full patency at the junction of the skin and the urethra. A background psychiatric illness was responsible for this action as in quite a number of reported cases. ${ }^{4,6}$ The challenge in the management involves obtaining the consent for partial or total penectomy and subsequent postoperative management, which involves getting the patient to accept the perineal utrethrostomy. This obviously calls for early involvement of the psychiatrist in the management.

In conclusion penile gangrene from a strangulating agent is uncommon. In this condition, the only operative option was a total penile amputation and definitive perineal urethrostomy. Getting the patient to accept this procedure is a serious challenge. This difficulty could be minimized by early involvement of the psychiatrist in the management. There is absolutely no option than a prompt and safe removal of the strangulating agent by whatever instrument is available. Removal of penile constricting devices can be very challenging and often requires resourcefulness and a multidisciplinary approach.

\section{REFERENCES}

1. Ivanovski O, Stankov O, Kuzmanoski M, Saidi S, Banev S, Filipovski V, et al. Penile strangulation: two case reports and review of the literature. J Sex Med 2007; 4: 1775-1780.

2. Osman M, AL Hafi R. Al Khadi H. Gangrene of the penis due to strangulation by a metallic ring. Scan J Urol Nephro. 1996; 30: 77-78.

3. Singh R, Singh A. Penile strangulation by multiple metallic rings, its treatment and use of hand Doppler. Internet J Urol 15288390, 2007: Volume 5 Issue 1.

4. Jain S, Gupta A, Singh T, Aggarwal N, Sharma S, Jain S. Penile strangulation by a hard plastic bottle: a case report. Indian J Surg 2004; 66: 173-175.

5. Punikar SV, Shroff PR, Vaze ML. An unusual case of strangulation of the penis by metal hammer head - (a case report). J Postgrad Med 1978; 24: 5859.

6. McGain F, Freedman D. Penile entrapment in a bottle: the case for using a diamond-tipped portable glass saw. BJU International 1999; 83: 10711072.

7. Bhat AL, Kumar A, Mathur SC, Gangwal KC. Penile strangulation. Br J Urol 1991; 68: 618-21.

8. Tauro LF, Roshan M, Rao BSS, Ravikrishnan J, Menezes LT. Fournier's gangrene of The penis. Indian J Plast Surg 2005; 38: 154-156.

9. Gillitzer R, Frazaring L, Hampel C, Pahernik S, Bittinger F, Thuroff JW. Complete gangrene of the penis in a patient with arterial vascular disease. Urology 2004; 64: 1231.

10. Vijayan P. Gangrene of the penis in a diabetic male with multiple amputations and follow up. Indian J Urol 2009; 25: 123-5.

11. Weiner DM, Lowe FC. Surgical management of ischaemic penile gangrene in diabetics with end stage atherosclerosis. J Urol 1996; 155: 9269.

12. Gauthier M. Obsevation d'un etranglemant des testicules et de la verge, occasionne Par le passage d'un briquette. J Med Chir Pharmacol(Paris). 1755; 3: 358.

13. Silberstein J, Grabowski J, Lakin C, Goldstein I. Penile constriction devices: case report, review of the literature, and recommendations for extrication. J Sex Med 2008; 5: 1747-57. 